This is an Author's Accepted Manuscript of an article published in Anthropological Forum, 18(1), 17-35, 2008 [copyright Taylor \& Francis], available online at:

http://www.tandfonline.com/10.1080/00664670701858927.

\title{
Counterparts: Clothing, Value and the Sites of Otherness in Panapompom Ethnographic Encounters
}

Will Rollason ${ }^{1}$ Department of Social Anthropology, Arthur Lewis Building, University of Manchester, M13 9PL, UK. Email: will.rollason@ yahoo.co.uk

Panapompom people living in the western Louisiade Archipelago of Milne Bay Province, Papua New Guinea, see their clothes as indices of their perceived poverty. 'Development' as a valued form of social life appears as images that attach only loosely to the people employing them. They nevertheless hold Panapompom people to account as subjects to a voice and gaze that is located in the imagery they strive to present: their clothes. This predicament strains anthropological approaches to the study of Melanesia that subsist on strict alterity, because native self-judgments are located 'at home' for the ethnographer. In this article, I develop the notion of the counterpart as a means to explore these forms of postcolonial oppression and their implications for the ethnographic encounter.

Keywords: Clothing; Papua New Guinea; Post-colony; Alterity; Ethnography

\section{Introduction}

When we blacks go to other places, we start hearing people talking about birds and we just fit in, but with whites, it's different: we deal with them as counterparts and just get along.

With these words, John Nigoyo, Headmaster of the Panaeati Primary School, tried to make me understand the impossibility of identifying myself with(in) the kinship world of Panapompom, a small island in the Louisiade Archipelago, in south-eastern Milne Bay Province, Papua New Guinea (PNG), where I did 18 months of fieldwork between November 2004 and June 2006. Characterising kinship as a mode of relating through the bird 'totems' of matrilineal clans (found throughout the region), as a point of cultural separation, he offered me an alternative vision of my alterity: as a 
counterpart. This article is devoted to exploring this tantalisingly vague, yet pregnant, spin on difference as an interpretive device and a contextualising motif for exploring post-colonial experiences of poverty on Panapompom.

The ethnographic importance of this discussion lies in the intensity of the work that Panapompom people put into placing me adequately in their social world. On one hand, there was a huge level of resistance to my aligning myself — and the colossal wealth that I was supposed to possess-with any family as a kin relation; hence $\mathrm{Mr}$ Nigoyo's definition of me as a non-kinship being. 'You haven't come for one man or one family', some told me, 'you have come for the whole community'. On the other hand, there was a nagging doubt about how I could stand in a productive relationship to a person, or persons, so loosely defined and socially unrecognisable as the "whole community'. As a general good, I attained a colossal spread of potential links, and with it, an untested level of social value that made my position highly ambiguous.

The ethnographic fix of being a counterpart broaches the anthropological question of alterity in an interesting way. Alterity has for a long time been at issue in the anthropology of Melanesia and beyond (Jackson 1987; Strathern 1995), frequently focusing on the post-colonial predicament as one in which alterity appears as a problem for anthropology, a difference to be qualified, explained, or otherwise overcome, often in terms of 'culture' or modes of speaking or writing that 'deal with' difference (Abu-Lughod 1991; Jackson 1996; Sahlins 2000). This has been as true of authors who attempt historical analyses of colonial and post-colonial relations (Bashkow 2006; Fabian 1983; Thomas 1991), as of those focusing on social change in the present (Robbins 2004; Robbins and Wardlow 2005). There is an excellent and extensive literature on the adoption and modification of Western and mission clothing styles in the Pacific and beyond (Colchester 2003; Küchler and Were 2005; Mosko 2002, 2007) that works in this vein, examining how Pacific people have worked to appropriate and 'indigenise' colonial clothing. This is a project aimed at showing that colonial values and capitalist economies do not overcome indigenous value systems (documented, for example, in Englund and Leach 2000; Gell 1993; Kasaipwalova 1974; Kuehling 2006; O’Hanlon 1989; Strathern 1979), but become part of them (Moore 2004). 
Lack of space must excuse my limited engagement with this literature here, for my project is different. The notion of being a counterpart leads me to engage with efforts on the part of PNG people to become the same as or similar to colonial others. This article therefore represents a parallel argument, running the other way; I am concerned with indigenous attempts to achieve similarity to (post-)colonial others, seen as an ethical project of development (Foucault 1997; Laidlaw 2002). My critical targets are not these studies of clothing as such, but anthropological strategies that depend on this difference, represented here, albeit crudely, as the New Melanesian Ethnography.

The notion of counterparthood that Mr Nigoiyo expressed to me was surely built on the sorts of relationships that structure the contacts local people have experienced with white people in the recent post-Independence past. ${ }^{2}$ These contacts were concentrated around the gold mine at Misima, which ceased operation in 2005, and a major 'community-based' conservation project undertaken across the province by Conservation International, ongoing at the time of my research (Conservation International 2001). Local people had experienced in these contexts what amounted to both an offer and a demand from white people that they, too, take part in the same work as white people did, while retaining their national-cum-ethnic marker as Nationals. Conservation International's project was, from the beginning, a 'stakeholder'-driven participatory exercise, in which capacity was to be built with the help of outside experts, who would train and empower local 'counterparts' to take over their work. Indeed, those elements of the project based on establishing lasting local committees and organisations especially included a local person whose role was explicitly as 'counterpart' to an expatriate whose position was seen as temporary and enabling; the latter's anticipated withdrawal would then leave a National at the helm.

Similar initiatives have become general practice in the employment policies of mines in the region (Imbun 2006). Although they may not employ the exact vocabulary, the 'localisation' of labour operates on the same stated principles of advancement to equal opportunities through the sharing of skills and knowledge, with stress placed on disciplining locals as professionals in their fields. Several Panapompom men had benefited from these 'capacity-building' schemes during their employment with 
Misima Mines, becoming machine operators, mechanics and so on-as counterparts to expatriate employees whom they then replaced.

Counterparthood offered Panapompom people an image of simultaneous national independence and capitalist affluence (LiPuma 1995) by proposing a world in which, given a proper standard of work, or a correctly managed life, the positions of wealth and success left vacant by the departure of the Australian administration in 1975 might become theirs. This represented both a claim to parity on the part of Panapompom people - potentially at least - and a serious ethical problem: the values that would govern the new lives to which they aspired appeared to be controlled elsewhere, enframing (Mitchell 1990) the efforts they were making on the basis of what they saw as limited and inadequate means. The problem for Panapompom people was to become equivalents or substitutes for white people in terms of values beyond their control.

For Panapompom people, the stakes were high, because the divide that people figured as establishing my counterpart status was exactly the divide people perceived between themselves and the centres of power, affluence and the morality in terms of which they framed their judgments of themselves. In making comments on the 'standard' (as they put it) of life on Panapompom, people would usually phrase value judgments by way of a detour through my eyes. People would remark that Panapompom must look primitive to me in comparison with the homes of white people, where everything is 'set'. In Panapompom people's self-judgments, I found myself speaking as an imagined locus of a critical, indeed judgmental, perspective on their lives, from a fantasy position foisted on me in the course of conversation. In this way, I became a censor and a judge through the co-option of my voice in ways that by turns disturbed and frustrated me. I thus found myself in an awkward position for an anthropologist: although I was making a huge effort not to make value judgments, almost all of my informants were constantly phrasing self-judgments that they could locate at a site they could identify with me. The vacant, connective possibilities of 'counterparthood' extended me into Panapompom social life as arbiter and critic, a fetishised voice and gaze that surveyed, condemned and oppressed. 
I do not think that this fluid and problematic dis-location of the anthropologist as subject is an unusual predicament for contemporary ethnographers. Debbora Battaglia (1999), in her manifesto for an 'ethics of the open subject', makes what is essentially an examination and understanding of these operations of self and other the basis for what she sees as an 'ethically responsible anthropology'. Battaglia's position, and my experience, call for an easy play with the loci of alterity, an acceptance that we can no longer try to draw the lines between 'the trading post, the hill fort and the sheep run', places of culture in Geertz's $(1973,16)$ classic formulation, and 'the book, the article, the lecture', as sites of anthropology. On the contrary, the anthropologist and his or her art have been captured as the site, content and tool of the native's 'culture', which thereby becomes not so much culture as a consciousness, a shadow-play of perceptions, perspectives and points of view, in which the voice of value and meaning is shifting and in motion (MacDougall 2006). This collapse of a single, stable or authoritative point of view prompts me to speak of post-colonial consciousness, the post-colony figuring the replacement of a singular hierarchy of vision and speech with an abundance of counterparts, a proliferation of alterity (Bhabha 2004, 2). I use this tag even though, as we shall see, many of the voices and points of view that speak to Panapompom consciousness are, in fact, highly 'colonial' in their character, tone and content.

Here, I investigate how clothing, kaliko in the local vernacular, comes to present an image of the relationships constituting Panapompom people's consciousness of their place in a post-colonial political economy, and what these relationships might be like. Panapompom people, especially women, often measure their perceived poverty in terms of their clothing. Raggedy clothes, good only for the garden and for work, dirty clothes, untouched by soap; these are both index and icon of economic failure, setting people apart from the fine appearance of white people, with their good, colourful things, boots and cleanliness. People judge their clothes, in particular, as qualitative markers of their difference from their image of white people. Dress becomes not something in itself, but an inadequate mime of the other, just as abilities to make money or pursue development and community goals are cast in terms of an image of the law and economy of an urban industrial state that Panapompom people have never seen or had any direct contact with. Thus, on the one hand, clothing causes the body to show the state of being poor, while, on the other, it holds out hope for extending 
relations, connections and identities towards the centres of power and affluence. Indeed, it would not be too strong to say that clothing serves as the medium for imagining the sorts of relationships that might exist between white people (dimdims) — the archetypal other — and black people, naitibs ('natives'), primitives, which for Panapompom people are the pejoratives of self.

I want to use these understandings to think about the general form and value of relationships for Panapompom people, and how they extend to the world, or the world to them. In doing so, of course, I am entering into the field in the act of writing; I can draw no hard distinction between the voices and connections I am making and those that my informants construct. I find myself truly inter alia, amongst others, in trying to understand just how it is that people know themselves as participants in a contemporary global economy.

\section{Other Clothes}

Koita and Andy, her husband, were once discussing money on a canoe trip I and some other lads made with them to Bwagaoia, the regional capital and what passes as a local urban centre. Money was probably on their minds at that time as they took their daughter, Dia, to begin her career as a student at the local high school. This enterprise would cost them in the region of K1, 000 a year, ${ }^{3}$ a huge amount of money for the area. 'Money', said Andy, 'has become a very big thing, the biggest thing at the moment. Finding money is very hard', he went on, half grim, half wondering, 'very hard.' Koita agreed with him. 'Just look at us', she said; 'we just wear raggedy old work clothes (sibauka); we have no time of our own (nige wala sauga)'. The other boys joked that, if she was worried, she should make herself a coconut fibre 'grass' skirt, loba, a garment that will be familiar from photographs taken in the region as late as the 1970s and early 1980s (see Battaglia 1990), but is not normally worn nowadays. Koita replied that she did not know how to make loba, let alone how to wear it. Her mother had never allowed her, insisting that she wear dimdim clothes, kaliko. Now, even if she wanted to, there was no way she could go back to loba; she was stuck with her rags until something in her life changed. 
Development and wealth for Panapompom people are all about appearances. If you ask people what the meaning of development is, at some point in their answers they will, without fail, say that development means, or happens, when the appearance of the place changes (рапиа ana awa $i$ sensi). Development changes are iron roofs replacing thatch; piped water; lamps that burn all night; maybe music played from radios; people eating rice and tinned meat; and, of course, people having good clothes to wear. Panapompom, people say, has not developed; there has been no change in the appearance of the place. It is just like this, the way our ancestors left it, people will say. In order to be developed, Panapompom would have to look like other developed places; it would have to develop not so much in their image, but as their image. In talking about poverty in her clothes, Koita was expressing exactly these sorts of connections: if she were rich, she would look rich. Better, perhaps, in order to be rich, she must (first?) look rich.

Creating appearances like this, of course, does require money in the first place. An iron roof is no small investment, and much more than most people feel they can afford. In a sense, the appearance of development does need to be underpinned by relationships that create money. Here people who dwell in the 'modern' or 'Western' world are on familiar ground. We would probably all expect money to follow in some relationship to wage labour, for example. However, Panapompom consciousness of value is not completely straightforward (in other words, like ours).

\section{Generations}

Remember that Koita knows neither how to make nor how to wear the traditional women's garment, loba. Her ignorance of how to make and wear the clothes her mother and grandmother would have worn is entirely normal nowadays for people her own age and younger. Elder women know how to manufacture these garments, but no longer do so. Certainly, by the early 1980s 'traditional dress', as people call it, was largely defunct in the immediate area of Panapompom, worn only by a few old women.

That style of dress consisted of, for women, a mid length coconut-fibre skirt, loba, blackened with mud in the case of married women, blackened and very long in the 
case of widows. Men wore a strip of Pandanus leaf tucked between the legs and secured by another strip, acting as belt-like underpants, as one informant put it. This was called sivi. Both sexes left the upper body uncovered, as they both sometimes still do in informal situations, decorating themselves with paint, colourful leaves, feathers and the valuable red shell-beads (bag) of kula fame. This style of dress is never seen nowadays, except when worn by schoolchildren compelled to wear 'traditional dress' on Fridays as part of their 'cultural education'.

What happened to traditional dress?

The first Methodist mission in the area was established by William Bromilow in the early 1890s on Panaeati, Panapompom's closest island neighbour (Berde 1974, 1979; Bromilow 1929). This time is beyond the recall of people now living on Panapompom. However, old men remember that even the oldest men wore a laplap, at least for church. Women's dress seems to have changed more slowly, although women soon began to wear blouses; mothers to middle-aged women might have worn loba, and their mothers certainly would have done. Later still, as the discourse of 'National Independence' developed, both men and women began to adopt European-style dress all the time, not just for church. Men of about forty and over usually insist on shirt and slacks for church and community functions, dressing down into more comfortable, or less respectable, clothing for work and informal socialising. Women follow suit, wearing sober skirts and blouses for church, although they often drop the blouse at home, hitching their skirts over their breasts as a slip, and wear heavily 'cut-off' tshirts.

Crudely, clothing marks off both the passage of the generations and the birth of the nation. This is particularly clear in the development of men's dress, especially as seen from the perspective of late middle-aged men, the generation that was growing up around the time of Independence. From their perspective, the progression from the pandanus sivi, to the laplap, to shirt and pants seems to inscribe the progression from the 'savage native' of the early colony to the oppressed black of the established colonial administration and, finally, to the full citizen of the independent state, Papua New Guinea. 
People today speak of sivi as amusing and quaint, even while conceding that they were practical and cool to wear. I do not believe that many people alive today ever saw many adult men wearing them. Indeed, the sivi is seen as one step away from the nakedness that is tolerated in small children before they are made to know that it is shameful to be naked and take it upon themselves to dress.

For males, the progression to the laplap marks the domination of PNG by paternalistic whites, and of the native as different and second class, more than as a different social type. One senior man whom I know continues to wear the laplap. He was given laplaps to dress in when he first went to mission school and never graduated from them. His contemporaries think of this as the dress of very junior people, small-boys. Laplaps are not proper garments for men and are not often worn in public. They are worn to sleep in and to wash, and in other situations where clothing is of less significance, for example when diving on small cays on the reef. On such trips, away from women, men often wear only their underpants. In these situations, the older men horse around with the younger, and the normal relationships of respect that characterise adult society at home seem to be suspended. Life in a laplap is very much similar to the life of the juvenile and unattached.

The final move for men of the Independence generation was to shirt and pants. They adopted this dress on leaving school, or else when they found some money of their own. ${ }^{5}$ It marks them out from their father's generation, almost all of whom would have worn laplaps, changing to trousers and/or putting on shirts only for special occasions. In this context, trousers and shirts are the dress of the fully adult, independent Papua New Guinean, and most elder men wear it with a high degree of pride and attention. It is this mode of dress that finally establishes a direct equivalence with dimdims, seemingly without a trace of the self-conscious, ironic mimicry that writers of the post-colonial elsewhere in the world have noted (Bhabha 2004; Taussig 1993). An equivalence of costume serves, in the context of Papua New Guinean clothing, to assert that Papua New Guineans are the same as Australians, but living in $P N G$. They therefore become, in the strongest sense, counterparts: opposite numbers at a different site. 
Taking dimdims as counterparts — and becoming their opposites in turn - the parity that independent styles of clothing create is more than just a symbol of style. It constitutes development, modelled on a development to adult parity in the passage of generations. Note that this inscription of development, figured as a conversion to modernity, was absolutely explicit in colonial policy of the 1960s and 1970s (Sharrad 2000, 2005). Moreover, the fetishisation of clothing as development is evident in elite PNG people's self representations, especially from the early Independence period (Matane 1972; Narakobi 1983). Shirts and slacks look as developed as they look grown up.

\section{Values}

As Michael Taussig $(1993,249)$ has noted, a common feature of mimesis and mimetic practices is that the mimic seems to acquire something of the character of the mimicked, even though he still retains his distance. The mimic partakes of the power of the mimicked in some sense, its qualities. In just this way, the act of taking dimdim clothing, of becoming a counterpart, projects onto naitibs the qualities of the dimdim. This projection is absolutely explicit. It was a popular joke amongst my Panapompom friends that our clique was made up exclusively of dimdims. People from outside our little posse would be told something like, 'you naitibs are so primitive. We dimdims are cleverer than you, so we know better.' It is a joke, but it has an edge. In the same way, a very close friend said to me on one occasion, after we had been telling some gratuitously sleazy jokes, that there was no way I could go home. 'Willie', he said, 'you are already too wicked to be a dimdim; you must stay on Panapompom'. Appearing in a particular way creates relationships and shared capacities, at least in theory (Strathern 1979, 1988). Perhaps here is the sting in the counterpart's tail: appearances imply but do not entail; a mimer is not the mime but rendered different by virtue of $i t$. I vividly recall one community meeting held to deal with some problems amongst the youth. The magistrate called on people to reform themselves. He said that if they were to develop they must act 'like organised people'. Note the comparison: not that to develop they must organise, but that to develop they must act as though they were organised; they must enact, or act out, organisation. For Panapompom people, this entails an organisation of appearances. 
Western notions of relations of production assume that relations between things precede the appearance of an effect. ${ }^{6}$ That is to say, those appearances are effects, not causes, not even really objects. We are accustomed to the idea that, for example, if a person looks ragged, starved and ill, or if he appears to be poor, it is because he is enmeshed in political and historical circumstances that transform the way he appears to us. Happenings, appearances, are because of or follow from preceding causes; but the call to 'act like organised people', just like Koita's mother forcing her into kaliko she can no longer afford, inverts this relationship. It is as if creating the image of development could bring it into being, as if the mime and the mimed were the same thing. The image itself seems to elicit the relations of production it entails, rather than revealing its disconnection from them. Viewed in this way, I see it as tragic that contemporary Panapompom people insist on wearing clothes to which they have no cultural or historical connection beyond the oppression of colonialism. However, I am suggesting that those same people see it differently, as the acquisition of relations through imitation and appearance. Rather than covering or obviating relations, the image reveals, suggests, and persuades them into being, at least as a possibility. Indeed, the covering image becomes the context that defines the equivalence of counterparts (Moore 1994).

This is a familiar sort of formulation in the context of the contemporary ethnographic theorising that has been produced around studies of Melanesia. For example, Strathern's (1992b) thesis is that gift exchange creates visible persons by a play of imagery that establishes certain relations as salient, while suppressing others that are inconsequential to the picture of the social to be made. She argues that the issue is not the creation of relatives out of non-relations but the making of visible relations out of an over-relational chaos of links (Strathern 1992a; see also Battaglia 1990). Thus, exchange is not, Strathern argues, performative as such, although it is a performance. It performs, and in so doing identifies and reduces, rather than creating, the relationships that define persons in particular aspects.

Here, I am suggesting something that is similar, but significantly different as a theoretical move. Rather than an image that limits and thus defines the contingent medley of a person, I argue that, in a context of historical openness and flux in the sites of otherness - that is, a post-colonial situation - images are too various and 
potentially distant from the bases of 'culture' to allow for their defining persons. Strathern $(1988,7)$, aiming at a general theory of the difference between Melanesian and Euro-American people, is willing to establish a watertight divide between the imagery each sort of person deploys. She finds it possible to argue that the imageries in question are in fact properties of the modes of personhood that define her two cultural spheres. I am suggesting here a situation in which imageries are on the move, which in turn entails a political debate, a rhetoric of imagery, a prospecting for meaning and significance in Battaglia's (1995) terms.

In these terms, development explodes onto the stage as an act in the fullest sense of the term, as something artful, made up, that explores the space between 'the really real and the really made up' (Taussig 1993, xvii). The mime of development uproots imagery from elsewhere, from another place, and transplants it as development itself. It consists in the imitation of the developed counterpart.

The effect of imagery like this, standing in for relations, is to create, as Marx (1977, 443ff) long ago appreciated, a fetish: something that stands above and beyond relationships of an 'objective' sort, but nevertheless appears to motivate them. This sort of theory has relevance here, not because it purports to distinguish between true and false consciousness but because it suggests that the imagination of relationships might be based on the creation or replication of images, which in fact float loose from any necessary connections to the relations of their production. In seeing an iron roof, 'organisation' or fine clothes as being development, therefore, Panapompom people are multiplying the fetishes that govern their consciousness. Fetish, here, seems to mark a metaphoric equation signalling plenitude, or identity, and obviating lack and difference. Here, I want to emphasise how, from a familiar 'Western' perspective based on an understanding of appearance as a sequel to relationships, the fetish covers a lack of timely, productive relations, for example, in the sequence, 'labour-moneyiron roof'. The obviating image, the fetish, stands as a synchronous gesture of identity: 'iron roof!' These things themselves become development, and not the effects of development. Development means changing the appearance of the place, but it does not entail establishing the relationships that would effect that change (as we would tend to see it). Rather, the images themselves appear to entail or cover those relationships, which can be assumed, because of what you see. In seeing, for example, 
the look of clothing as wealth, people become divorced, or alienated, from their capacity to create wealth, since value is not seen to subsist in labour, even money, but in the appearance of money spent. Knowing development is seeing it, but seeing it is making the image, not creating the systems and relations that would make it appear.

\section{Counterpart Clothes}

In order to understand more adequately how this organisation of imagery translates into a consciousness of the world, or a notion of a place in it, we need to understand more about the location of these images; most specifically, we need to answer the question: whose are they?

Think about Koita's mother, forcing her daughter to wear kaliko. There is in a sense a curious dynamic to that relationship, in that, as everyone will recognise, loba had a certain practicality. For one thing, any woman could manufacture them. Also, when they got dirty they were simply thrown away, or a new skirt could be layered over an older one. It was not the clothing of the money economy, and it did not involve people in relationships that made them poor. The old woman, however, forced her daughter into the new style of clothing and forbade her the old. This action, as I have argued, seemed aimed at giving her the prospect of powerful connections and making her into a new sort of person, with a new consciousness of relating. Now, however, Koita sits in her raggedy sibauka and feels that she is not living that image properly. She feels herself to be poor and excluded from the very relationships she seems to wear on her body, the relationships to which she aspires. Who exactly is calling her a failure, though?

I think the answer is that it is her clothes. That is to say that, through the unrealised relationship she embodies through her dress, she acquires a voice that criticises her, a gaze that judges her performance as second rate. If you talk to people about contemporary clothing, they will always say that, regardless of the fact that they wear it, it does not belong to naitibs. When someone wore a particularly worn pair of pants or an outrageously torn t-shirt, for example, people would remark that kaliko belonged to dimdims: 'natives', they would say, 'are sigasiga ['wicked', 'foolish', 'thoughtless'] and wear it just any old how'. This sort of default possession of products by dimdims 
is seen elsewhere too: iron-roofed houses are dimdim houses (limi-dimdim), diesel work-boats are dimdim boats (waga-dimdim) and so on. Money and the things bought with it are generically 'dimdim things', or the 'dimdims' game'. Natives see themselves as structurally ignorant of these things.

In Panapompom discourse, the things that come from dimdims retain their connections to the centres of wealth and power even as they move into naitib hands (cf. Mauss 1954; Weiner 1992). Indeed, in the Panapompom enactment of the dimdim whom the acquisition of valuable things represents, the things themselves seem to possess the naitib and not the other way around. Thus, when a black person dons a collar and tie, it does not so much belong to him as he belongs to his clothes, in the sense that, in miming the appearance of the dimdim, he makes a claim to the relationships, the links, that appearance implies; he plays with that identity, with that fetish, with that point of view. The appearance of the dimdim is wealth and success. So, for example, living in town, with the easy flow of money and goods that represents, can be called 'doing the dimdim' (lolodimdim), appearing as if a dimdim. Indeed, the easy urban lifestyle is thought to soften and lighten the skin, just as a hard life at home, sweating it out in the burning sun, is thought to make one darker. Equally, dimdims who act native get darker. My stay on Panapompom made me, most people agreed, so 'black' as to be almost like a native. In taking on dimdim appearance in dimdim clothing, black people see themselves as acting out the relational qualities of dimdims and their modes of connectivity. It becomes a claim or assertion that sees Panapompom people slide into the pejorative: naitib, primitive, failures from the perspective of their clothes.

Clothing in this interpretation becomes the locus of gaze. Clothing stands in for a counterpart: an opposite number in a different situation. But this counterpart is not a hard-and-fast other, but an act to be acted, a shirt to be put on. The other becomes a place to be as much as the self, and serves to displace either. In putting on dimdim clothes, people seem to feel that they put on the relationships the counterpart stands for and, in the process of this mime, they become possessed by the voice and gaze of the other, which censures them for the quality of their act. People come to be criticised by voices and persons that inhere in the clothes they are trying to wear. By 
putting on the costume and entering into the mime, people talk the talk that is critical of their own attempts to walk the walk.

Thus, the image of the old woman, Koita's mother, putting her daughter into a new, colourful cotton skirt, is a concrete image of the creation of domination and a subject of sorts, a modern subject in the gaze of others who are simply displacements or imaginations of the self. It is an image of the passing on of failure from one generation to the next, indeed the creation of failure in a generational divide. Koita's mother was not a failure, because the imagery that she acted out did not cause her to be possessed by such distant and demanding others. Her dress, which, without precedent in metropolitan repertoires, marked her as the irreducibly different other of the colonial gaze, also spared her the sort of value judgment that is reserved for people who are 'the same but different': counterparts. The current predicament is only possible in the post-colony, where the collapse of single-source, authoritative voices has opened the field for an influx of otherness, a huge increase in the credible and audible voices and sites of alterity, positions for the self. Koita's skirt propels her into this realm of parity, the situation of being inter alia, amongst others, mimicking them as they enfold and follow her form, becoming the outer layer, her point of contact with the world.

It is only in this visualised, mimetic relationship that Panapompom people's consciousness of poverty and oppression comes into being. Naitib consciousness only makes sense in relation to dimdim, or, rather, the consciousness of dimdim. Naitib consciousness is born of the gaps between people and their clothes. Taussig $(1993,17)$ asserts that the power of mimesis is in finding the self through the detour of the other (cf. Rabinow 1977), and thus the acquisition of some sort of power and control over both. Thus, the mime entails difference, however subtle, that marks the mimer off from the mimed. The mimer comes to an understanding, a relationship with his other; he explores him but, ultimately, retains his separation. This is the nature of consciousness (Žižek 1999). It is a particular feature of naitib consciousness that it is born of the adoption of, or possession by, dimdim perspectives in the course of the mime. These become the moral condemnation of the mime, by the mimer, in the voice of the mimed. In this situation, however, can we even make those distinctions? Koita wears a raggedy dress that ambiguously attaches to her as a naitib and to me as a 
dimdim; when she speaks of her poor clothes, the voice she seems to speak in is, much against my will, mine.

\section{No Time of Our Own}

At the beginning of Argonauts of the western Pacific, Malinowski (1922, 4) makes a wonderfully ingenuous, even innocent, statement of his colonial pedigree, which might serve as a manifesto for his whole time and œuvre. He asks his readers to imagine arriving on a far shore and seeing for the first time the strange inhabitants, whom it is their job to understand, decode, imagine and write. This is a fine statement of the colonial vision, in which the native appears, with no consciousness or imagination of his own. The conviction of Malinowski's successors, British structural-functionalists, and of their French and American counterparts, that an authentic native consciousness could exist of itself, but only for itself, in the form of relations or symbols that were comprehended as purely self-referential, served to make the native into anthropology's object. Colonial anthropology of this type made natives real and controllable, but elided the means by which they became real (for us): through our relationship to them. Natives were different, yet transparent to the anthropological gaze because, ironically, they were cut off from the dimdim to purify them, in Latour's (1993) terms - to exclude the contingency and history that would clog the workings of a functional structure. This separation has the effect of exclusion from a common time (Fabian 1983).

The New Melanesian Ethnography, especially as represented in the work of Strathern (1988) and Wagner $(1975,1986)$, takes and exploits this exclusion and separation as the principal fact in its appreciation of the relation between Melanesia and EuroAmerica, by employing it to examine the nature of knowledge of other people across a divide that it considers a total bar to understanding (Strathern 1988, 16). Both Strathern and Wagner, different though their thought is, make their project the understanding of Melanesia by studying how it does not translate into the terms of modern social science. This is the basis of Strathern's 'analogic method'. In the process, and by retaining the dimdim/naitib divide as absolute, they avoid the sticky problems of power and knowledge, oppression and its consciousness that their contemporaries largely failed to overcome (Clifford and Marcus 1986; Marcus and 
Fischer 1986). The strength of the New Melanesian Ethnography is to create a powerfully relative understanding, while avoiding a slide into the ethical quagmire of post-coloniality.

The relations between naitib and dimdim are well expressed by Wagner (1986, 92-95) in terms of a construction of time, in a mode that he terms epochal. His contention is that the time of experience does not deal in duration as such, which is an illusion of mechanical time-keeping devices. Instead, it is concerned with transformative shiftsfigure to ground, inversion, obviation-by which one image can be seen to have replaced another. Thus, time in general can be modelled on the time of ritual, which proceeds according to these flip-flops amongst images, creating itself as a succession of obviations. This construction also serves to unite naitib and dimdim in time, as obviating transformations of one another, as if they were successive images in ritual. Hence, Wagner is able to exploit the colonial rift between self and other, ironically, to unite them as moments in the other's time, granting them common ground in history, of a sort (cf. Strathern 1988, 303).

Although this is powerful stuff, and applicable to my own material, there is a problem: how to sustain the hard difference on which both Wagner and Strathern base their theories. As I have shown, I appear on both sides of that divide, not merely as an image, an idea or fantasy, in Strathern's $(1988,4)$ terms a 'glimpse' of the other, but as a fully fledged social actor, an other who criticises, oppresses and condemns. I cannot avoid the post-colonial problem, the problem of being a counterpart, even if it means facing impossible ethical demands and almost certain intellectual failure. What I need to ask is on what terms and by what means do I become the censor of the other, the voice the other uses in his or her self-oppression? This is not a question of how I relate, but of what my relationship is, and it demands a fine-grained causal time that can register the contingency of relationships, a thing that the obviation-time of rituals is ill-suited for as an intellectual tool. At the same time, though, I need to avoid becoming the colonial interrogator Panapompom people seem intent on making me, which means that I need to form this relationship on terms that I draw from our conversation. 
In order to think this through, some consideration of time is warranted, specifically the time that Koita felt herself excluded from when she lamented, 'nige wala sauga', there is no time of our own.

What kind of time might be embedded in clothing? In the fetishised universe of Panapompom clothing, productive relations are elided, or obviated, by appearances; wearing a certain sort of clothing is a way to become developed. This is a metaphor, in that it asserts an identity in an image, covering up differences. There is no temporal development in the metaphor, rather a radical flattening of time: the metaphor replaces co-evality with co-presence. Thus, metaphor does violence to generational, developmental or historical time, in eliding the space and distance between things separated by their histories. The metaphoric claim to relations through clothes becomes a loss of history in favour of context and co-presence, which obviates the productive relationships that create values.

Hence, the development of clothing becomes not a self-history but a vision, located today in the age of shirt and pants, that sees the pre-independence generation as slightly absurd others in their traditional dress or laplaps. It is a vision of history that is entailed in a metaphorical spatial move, crossing the frontier of difference that defined the old men, into alignment with dimdims. The power of the dimdim voice seems to create the situation where there is no 'authentic' locus of value. In clothing, all value appears to be lodged elsewhere from a Panapompom perspective, attached to the counterpart. Here, agency, or labour, becomes truly, in Strathern's $(1988,272)$ terms, 'action with another in mind'. However, the terms of agency are not being set reciprocally, but attached, at least notionally, to an outsider. There is thus no way the production of value can be used as a measure of time, or the development of relations become the development of an authentic history.

On one occasion, I was told a story that exactly illustrated this kind of movement. Madeline told me about the first time she had seen a helicopter land on the neighbouring island of Panaeati. She was one of the schoolchildren who all rushed out to look. The old women, dressed in their loba, were equally fascinated and also gathered to see. When the time came for the helicopter to take off, the pilot warned everyone to stand well clear, but they took no notice and pressed around the machine 
as closely as they dared. As the rotors began to spin, there was a great wind- 'that wind you get when a helicopter takes off', noted Madeline, knowingly—and all the old women's loba flew up into their faces; a grass skirt cannot be held down the way a kaliko one can because it is not all one piece. Humiliated and confused, they held their clothes together as best they could and ran for the bush. Madeline remarked that 'in those days, people weren't very modern: those old women had never seen a helicopter before in their lives!'

Madeline spoke as a savant on the subject of helicopters, claiming a place in the sphere of those for whom flying machines are everyday occurrences, and simultaneously excluding her mother's generation from that circle by means of their clothes. The helicopter was a means of revelation: it revealed a childish nakedness, and sent the ignorant naitibs fleeing into the bush, leaving dimdims and their associates watching the helicopter take flight. Here is the time of reproduction, figured as the time of generations. It is also similar to the sort of epochal time described by Wagner, except the development from one generation to the next, one epoch to the next, involves a movement across the line of difference that separates the West from the rest. The productivity of native, reproductive time is obscured by the spatio-temporal claim embodied in a printed cotton skirt.

This is not the time of the structured development of images but the time of an attempt on the other. Time is constituted in this story as a development in the fetishised other, a shift in locations, stitching across alterity. Hence, the historical aspect of this tale is the identification between Madeline and her contemporaries and the dimdim helicopter pilot, which establishes naitib as other to them all. What happens, however, in this translation between times, places and genres, is not an experience of plenitude, of 'really being' the other, but of lack. The lack figured here is the lack of productive relations underpinning the image, which is felt and seen as raggedy old clothes.

Panapompom people experience this move across, this attempt on the other in mime, as a falling through, a detachment from position. They find themselves possessed by the things they desire, yet simultaneously dispossessed. They find themselves inside an image without the means for projecting it. This is the movement from self to other, 
but without the authentic time of production that might support it. In this sense, not only voice and ethics but also time, figured as the simultaneity of the fetish, belong to the dimdim.

If Panapompom people see poverty or failure in their clothes, and locate time in the dimdim, we seem to be face to face with a very real oppression that flows across the boundaries of alterity, creating a colonial relationship between people and their imaginations.

\section{Conclusions}

The essential issue here is the way in which Panapompom people appear to create relationships through the imitative performance of imagery. This mode of performativity entails relationship, rather than a strictly symbolic relation, because it depends on the historically contingent quality of the other, rather than any preexisting cultural form. Trousers and blouses are not in any sense prefigured in Panapompom cultural imaginaries. Through this imitation comes an understanding or judgment of the self. In this particular case, the other is imitated as a dimdim, and a component of this mime entails the adoption of an imagined gaze or voice, which simultaneously condemns the naitib mimic as a part of that mimicry. It could be said that the commodities and values for which Panapompom people strive take the form of gifts, in that they embed not merely a value but a relationship, which is effected in the act of possession. Here, 'possession' is indeed the word; possessing an object appears to render its possessor possessed by the other who is imagined as its source. Dimdims attach themselves to dimdim things: trousers speak with the voice of the patrol officer.

This is a particular kind of attachment to, or enmeshment in, the world economy. It is not a strictly economic suction, because the money economy is only very weakly articulated to Panapompom, and, although at times it is certainly high in people's minds, they also display a happy-go-lucky attitude to whether or not they have money, which is never a necessity. Indeed, it follows from the path taken in this paper that the actual relations of the global economy are essentially beside the point. It is the appearance of the global marketplace that is significant. Value does not seem, in these 
relations of mime and mimicry, to inhere in the underpinning entrapment of one thing in another, or of one person in another, but to be demonstrated as an inferred relationship at the point of revelation, even if it is unclear what the quality of that relation might turn out to be. We have seen that the imagery of a modern, independent state or nation manifests itself in clothing, a pass at the development dimdims seem to represent, but there is little or nothing in the way of underlying structure that might bring that development about. Instead, there is a multiplication of fetishes, jostling one another as people attempt to define the true form of the good, of the modern and of affluence.

What really is moot here, then, is not difference or alterity as such, but the fantasy of the other, the sites of the self and the movements between them. It is a notable feature of my ethnographic experience that $I$ have been one of the crucial sites of otherness and selfhood. The oppression we have seen is essentially a resurrection of colonial visions in the self-definition of naitibs as against dimdims, but without the benefit of a colonial power. Self-oppression, perhaps false consciousness, is the order of the day. It is ironic that a self-consciously post-colonial anthropology should be confronted with such an openly colonial set of people. However, this merely serves to amplify Battaglia's $(1999,114)$ comment that closed questions, be they about identity, value or the significance of things, need to be undermined by the anthropologist, regardless of the store our collaborators put in them. The 'colony' that afflicts Panapompom selfimages is not colonialism as an object, but the image of colonialism, carried in artefacts like clothes. Infecting time, people and value, it injects in people feelings of failing and being left out. This is the nature of their consciousness, to an extent, in and of the global economy. It is also the point of their relationship to it, or joining with it. By imagining that dimdim values in some way define the nature of the good life, Panapompom people have already made themselves victims of global capital, regardless of how 'Melanesian' they are.

On the subject of Melanesia, we also need to take theoretical stock of our position visa-vis the New Melanesian Ethnography. This scholarship rests on an attempt to create knowledge of Melanesian people by analogies and metaphors, exploiting Their (supposed) radical difference from Us. The New Melanesian Ethnography represents a powerful internal critique of social science. It becomes problematic when applied to 
actual ethnographic encounters because of the divide between dimdim and naitib that it induces. Any ethnography of Melanesia that makes claims based on the radical difference of Melanesians and Westerners is guaranteed to elide the nature of the encounters by which consciousness of this sort comes into being. This is still a problem in the contemporary ethnography of PNG, which remains enamoured of the hard alterity of the first-contact native ( $c f$. Taussig 1993, 254).

Rather than employing the Gift as a marker of difference between an Us and a Them, we need to consider actual historical ways in which commodity economies entrap and collect Melanesians and inflict damage upon them, not necessarily in terms of cultural or environmental damage but in terms of their consciousness and self-understanding. This is surely the most gleaming possibility for post-colonial anthropology in this region.

Rather than avoiding the ethical minefield of the post-colonial predicament and the very real relationships and oppressions that it entails, we need to allow ourselves access to the other, and the other to us, in order to explore the quality of others and their relational capacities in the eyes of our others, even, indeed especially, when we function as the other to the other. This is not the sort of operation that the New Melanesian Ethnography will support. Mine is not a criticism as such, but perhaps a call for a move beyond the confines of these theories into the more open and infinitely more dangerous seas beyond.

\section{Notes}

${ }^{1}$ Acknowledgments: This research was made possible by an Economic and Social Research Council studentship, numbered PTA-030-2003-00496. I thank the National Research Institute of Papua New Guinea, my wife, Ilva, and my friends and informants on Panapompom and beyond for supporting my field research. I was wholeheartedly supported by Karen Sykes, Keir Martin, and Debbora Battaglia, who read earlier drafts of the manuscript and offered useful comments.

${ }^{2}$ The Oxford English Dictionary (1989) offers these relevant definitions of the term 'counterpart' in addition to local understandings: 'a duplicate, or exact copy'; 'a 
person or thing so answering to another as to appear a duplicate or exact copy of it'; 'a person or thing not exactly similar to another, but serving as its equivalent in a different context'. (OED Online 2007. http://dictionary.oed.com/cgi/entry/50051988?) ${ }^{3}$ The Kina $(\mathrm{K})$ is the national currency of PNG. At the time of my fieldwork, K1 was equal to approximately $£ 0.17$.

${ }^{4}$ Sudest, noted as a 'backward', highly traditional, and very dangerous place, is still an area where people claim that a lot of loba are worn.

${ }^{5}$ These distinctions no longer exist: schoolchildren today wear pants and t-shirts in children's sizes and styles.

${ }^{6}$ I use the notion of relations of production loosely here. Rather than make the ontological assertion that they are true relations hidden by false consciousness and mystification, I create an epistemological one, that we hold them to be true causal relations.

\section{References}

Abu-Lughod, L. 1991. Writing against culture. In Recapturing anthropology: Working in the present, edited by R. G. Fox, 137-162. Santa Fe, NM: School of American Research Press.

Bashkow, I. 2006. The meaning of whitemen: Race and modernity in the Orokaiva cultural world. Chicago: University of Chicago Press.

Battaglia, D. 1990. On the bones of the serpent: Person, memory, and mortality in Sabarl Island society. Chicago: University of Chicago Press.

Battaglia, D. 1995. On practical nostalgia: Self-prospecting among urban Trobrianders. In Rhetorics of self-making, edited by D. Battaglia, 77-96. Berkeley, CA. and London: University of California Press.

Battaglia, D. 1999. Towards an ethics of the open subject. In Anthropological theory today, edited by H. L. Moore, 114-150. Cambridge: Polity Press.

Berde, S. 1974. Melanesians as Methodists: Economy and marriage on a Papua and New Guinea island. PhD thesis, University of Pennsylvania.

Berde, S. 1979. Impact of Christianity on a Melanesian economy. Research in Economic Anthropology 2: 169-187.

Bhabha, H. K. 2004. The location of culture. London and New York: Routledge. 
Bromilow, W. E. 1929. Twenty years among primitive Papuans. London: Epworth.

Clifford, J., and G. E. Marcus. 1986. Writing culture: The poetics and politics of ethnography. Berkeley and London: University of California Press.

Colchester, C. 2003. Clothing the Pacific. Oxford: Berg.

Conservation International. 2001. Community-based costal and marine conservation in Milne Bay Province. Washington DC: Conservation International.

Englund, H., and J. Leach. 2000. Ethnography and the meta-narratives of modernity. Current Anthropology 41: 225-248.

Fabian, J. 1983. Time and the other: How anthropology makes its object. New York: Columbia University Press.

Foucault, M. 1997. Ethics: Subjectivity and truth, vol. 1. The essential works of Foucault, 1954-1984. New York: New Press.

Geertz, C. 1973. The interpretation of cultures: Selected essays. New York: Basic Books.

Gell, A. 1993. Wrapping in images: Tattooing in Polynesia. Oxford: Clarendon Press; New York: Oxford University Press.

Imbun, B. Y. 2006. Local laborers in Papua New Guinea mining: Attracted or compelled to work? The Contemporary Pacific 18: 315-333.

Jackson, A. 1987. Anthropology at home. London and New York: Tavistock Publications.

Jackson, M. 1996. Things as they are: New directions in phenomenological anthropology. Bloomington: Indiana University Press.

Kasaipwalova, J. 1974. 'Modernising' Melanesian society: Why, and for whom? In Priorities in Melanesian development, edited by R. J. May, 451-454. Canberra: The Australian National University.

Küchler, S., and G. Were. 2005. The art of clothing: A Pacific experience. London: University College London Press.

Kuehling, S. 2006. Dobu: Ethics of exchange on a Massim island. Honolulu: University of Hawai'i Press.

Laidlaw, J. 2002. For an anthropology of ethics and freedom. The Journal of the Royal Anthropological Institute 8: 311-332.

Latour, B. 1993. We have never been modern. Cambridge, Mass.: Harvard University Press. 
LiPuma, E. 1995. The formation of nation states and national cultures in Oceania. In Nation making: Emergent identities in postcolonial Melanesia, edited by R. J. Foster, 33-68. Ann Arbor: University of Michigan Press.

MacDougall, D. 2006. The corporeal image: Film, ethnography, and the senses. Princeton, N.J.: Princeton University Press.

Malinowski, B. 1922. Argonauts of the western Pacific. London: G. Routledge and Sons.

Marcus, G. E., and M. M. J. Fischer. 1986. Anthropology as cultural critique: An experimental moment in the human sciences. Chicago: University of Chicago Press.

Marx, K. 1977. Selected writings, editec by D McLellan. Oxford: Oxford University Press.

Matane, P. 1972. My childhood in New Guinea. London: Oxford University Press.

Mauss, M. 1954. The gift: Forms and functions of exchange in archaic societies. Glencoe, Ill: Free Press.

Mitchell, T. 1990. Everyday metaphors of power. Theory and Society 19: 545-577.

Moore, H. L. 1994. A passion for difference: Essays in anthropology and gender. Bloomington: Indiana University Press.

Moore, H. L. 2004. Global anxieties: Concept metaphors and pre-theoretical commitments in anthropology. Anthropological Theory 4: 71-88.

Mosko, M. S. 2002. Totem and transaction: The objectification of tradition among the North Mekeo. Oceania 73: 89-110.

Mosko, M. S. 2007. Fashion as fetish: The agency of modern clothing and traditional body decoration among North Mekeo of Papua New Guinea. The Contemporary Pacific 19: 39-83.

Narakobi, B. 1983. The Melanesian way. Port Moresby and Suva: Institute of Papua New Guinea Studies and Institute of Pacific Studies.

OED Online. 2007. The Oxford English Dictionary, second edition (1989). Oxford: Oxford University Press.

O'Hanlon, M. 1989. Reading the skin: Adornment, display, and society among the Wahgi. London: Trustees of the British Museum by British Museum Publications.

Rabinow, P. 1977. Reflections on fieldwork in Morocco. Berkeley: University of California Press. 
Robbins, J. 2004. Becoming sinners: Christianity and moral torment in a Papua New Guinea society. Berkeley, CA: University of California Press.

Robbins, J., and H. Wardlow. 2005. The making of global and local modernities in Melanesia: Humiliation, transformation, and the nature of cultural change. Aldershot and Burlington, VT: Ashgate.

Sahlins, M. D. 2000. The return of the event, again. In Culture in practice: Selected essays, edited by M. D. Sahlins, 293-351. New York: Zone Books.

Sharrad, P. 2000. Trading and trade-offs: Textiles and texts in the Pacific. New Literatures Review 36: 46-62.

Sharrad, P. 2005. Translations: Texts and textiles in Papua New Guinea. In The art of clothing: A Pacific experience, edited by G. Were and S. Küchler, 123-134. London: University College London Press.

Strathern, M. 1979. The self in self-decoration. Oceania 49: 241-257.

Strathern, M. 1988. The gender of the gift: Problems with women and problems with society in Melanesia. Berkeley CA: University of California Press.

Strathern, M. 1992a. Parts and wholes: Refiguring relationships in a post-plural world In Conceptualizing society, edited by A. Kuper, 75-106. London: Routledge.

Strathern, M. 1992b. Qualified value: The perspective of gift exchange. In Barter, exchange and value, and anthropological approach, edited by C. Humphrey and S. Hugh-Jones, 169-192. Cambridge and New York: Cambridge University Press.

Strathern, M. 1995. Shifting contexts: Transformations in anthropological knowledge. London and New York: Routledge.

Taussig, M. T. 1993. Mimesis and alterity: A particular history of the senses. New York: Routledge.

Thomas, N. 1991. Entangled objects: Exchange, material culture, and colonialism in the Pacific. Cambridge, Mass: Harvard University Press.

Wagner, R. 1975. The invention of culture. Englewood Cliffs, N.J.: Prentice-Hall.

Wagner, R. 1986. Symbols that stand for themselves. Chicago: University of Chicago Press.

Weiner, A. B. 1992. Inalienable possessions: The paradox of keeping-while-giving. Berkeley CA.: University of California Press.

Žižek, S. 1999. Of cells and selves. In The Žižek reader, edited by S. Žižek, E. L. Wright, and E. Wright, 302-320. Oxford UK and Malden MA: Blackwell. 